\title{
Comment on "Gastric and colon metastasis from breast cancer: case report, review of the literature, and possible underlying mechanisms"
}

This article was published in the following Dove Press journal:

Breast Cancer - Targets and Therapy

24 February 2017

Number of times this article has been viewed

\author{
Amin Talebi Bezmin Abadi \\ Department of Bacteriology, Faculty \\ of Medical Sciences, Tarbiat Modares \\ University, Tehran, Iran
}

\section{Dear editor}

I have read the interesting case report by Villa Guzmán et al recently published in Breast Cancer (Dove Med Press). ${ }^{1} \mathrm{~A}$ female heavy smoker was diagnosed with lobular breast cancer. The authors hypothesized that Helicobacter pylori infection can attract chemokines attributed with local inflammation which ends in tumor cells' migration. Concerning $H$. pylori and the presented hypothesis, I have some points which are listed as follows.

Attributing the presence of $H$. pylori to the breast tumor needs attention regarding further steps and whether the new strategy would involve designing a novel treatment for this kind of patient. To my knowledge, it is not possible to draw such a conclusion as seen in this case report.

No molecular mechanism was suggested to support this hypothesis. Indeed, it will be a novel finding if $H$. pylori colonization is proven to be related to breast cancer cell migration. H. pylori is a causative agent of chronic infection that lasts for decades in the case of ineffective therapy. ${ }^{2,3}$ Any effects related with this infection should be thoroughly investigated since it is not easy to imagine such unclear association with breast cancer cells' migration.

Finally, the result of the current study by Villa Guzmán et al can be a starting point for other investigators to examine the possibility of this suggestive idea. More in vivo and ex vivo studies are absolutely required before accepting this claim.

\section{Disclosure}

The author reports no conflicts of interest in this communication.

Correspondence: Amin Talebi Bezmin Abadi

Department of Bacteriology, Faculty of Medical Sciences, Tarbiat Modares University, P.O. Box |4|I5-III,

Tehran, Iran

Tel +982182884883

Fax +98 21 82884883

Email Amin.talebi@modares.ac.ir

\section{References}

1. Villa Guzmán JC, Espinosa J, Cervera R, Delgado M, Patón R, Cordero García JM. Gastric and colon metastasis from breast cancer: case report, review of the literature, and possible underlying mechanisms. Breast Cancer (Dove Med Press). 2016;9:1-7.

2. Abadi AT, Kusters JG. Management of Helicobacter pylori infections. BMC Gastroenterol. 2016;16(1):94.

3. Abadi ATB, Ierardi E, Lee YY. Why do we still have Helicobacter Pylori in our Stomachs? Malaysian Journal of Medical Sciences. 2015;22(5):70-75. 
Dove Medical Press encourages responsible, free and frank academic debate. The content of the Breast Cancer: Targets and Therapy 'letters to the editor' section does not necessarily represent the views of Dove Medical Press, its officers, agents, employees, related entities or the Breast Cancer: Targets and Therapy editors. While all reasonable steps have been taken to confirm the content of each letter, Dove Medical Press accepts no liability in respect of the content of any letter, nor is it responsible for the content and accuracy of any letter to the editor.

Breast Cancer - Targets and Therapy

Dovepress

\section{Publish your work in this journal}

Breast Cancer - Targets and Therapy is an international, peerreviewed open access journal focusing on breast cancer research, identification of therapeutic targets and the optimal use of preventative and integrated treatment interventions to achieve improved outcomes, enhanced survival and quality of life for the cancer patient.

Submit your manuscript here: https://www.dovepress.com/breast-cancer---targets-and-therapy-journal

The manuscript management system is completely online and includes a very quick and fair peer-review system, which is all easy to use. Visit http://www.dovepress.com/testimonials.php to read real quotes from published authors. 